\title{
Factors associated with morphometric brain changes in cognitively normal aging
}

\author{
Renata Eloah de Lucena Ferretti-Rebustini', Wilson Jacob-Filho², \\ Claudia Kimie Suemoto², José Marcelo Farfel², Renata Elaine Paraiso Leite ${ }^{3}$, \\ Lea Tenenholz Grinberg ${ }^{4}$, Carlos Augusto Pasqualucci ${ }^{4}$, Ricardo Nitrini ${ }^{5}$
}

\begin{abstract}
Objective: Cognitive impairment is associated with reductions in brain weight and volume. The factors related to morphometric brain changes in cognitively normal aging remain unknown. We aimed to identify which clinical factors are associated with morphometric brain changes in cognitively normal aging. Methods: A cross-sectional study of 414 subjects, $\geq 50$ years old submitted to clinical assessment and brain autopsy, after informed consent, was carried out at the São Paulo Autopsy Service, Brazil. Data on cognitive and functional evaluations were collected through structured interview applied to the next-of-kin. Brain weight $(\mathrm{g})$ and volume $(\mathrm{mL})$ measurements were obtained and adjusted for head circumference $(\mathrm{cm})$. Associations between brain weight/volume and related factors were obtained through univariate and multivariate analysis. Results: Participants were predominantly male (60.4\%), Caucasian (69\%), with mean age of $67.1 \pm 10.9$ years. Mean brain weight was $1219.2 \pm 140.9 \mathrm{~g}$, and mean brain volume was $1217.1 \pm 152.3 \mathrm{~mL}$. Head circumference was independently associated with low brain weight $(p<0.001)$ and volume $(p<0.001)$. Total and adjusted brain weight and volume decreased in some conditions. Female gender $(p<0.001)$, hypertension $(p<0.009)$, coronary artery disease $(p<0.013)$ and walking assistance $(p<0.011)$ were associated with lower adjusted brain weight while schooling was associated with higher adjusted brain weight $(p<0.003)$. Female gender $(p<0.001)$, age $(p<0.001)$ and hypertension $(p<0.011)$ were associated with low adjusted brain volume. Conclusion: Morphometric brain changes occur despite the absence of cognitive impairment and were predominantly associated with age, female gender, mobility impairment and cardiovascular conditions. Schooling may be a protective factor.
\end{abstract}

Key words: aging, cephalometry, brain/anatomy \& histology, health of the elderly.

\section{FATORES ASSOCIADOS ÀS ALTERAÇÕES MORFOMÉTRICAS ENCEFÁLICAS DURANTE 0 ENVELHECIMENTO SEM COMPRO- METIMENTO COGNITIVO}

RESUMO. Objetivo: 0 comprometimento cognitivo está associado à redução de massa e volume encefálicos. Fatores associados às alterações morfométricas crânio-encefálicas durante 0 envelhecimento cerebral normal são escassos. Nosso objetivo foi identificar quais os fatores clínicos associados às alterações morfométricas encefálicas em indivíduos sem comprometimento cognitivo. Métodos: Estudo transversal, realizado no Serviço de Verificação de óbitos da Capital, em São Paulo - Brasil, em que 414 indivíduos, com idade $\geq 50$ anos, foram submetidos à avaliação clínica e autópsia encefálica, após consentimento informado. A avaliação cognitiva e funcional foi obtida por meio da entrevista com familiares. Massa (g) e de volume $(\mathrm{mL})$ encefálicos foram obtidos e ajustados para o perímetro cefálico $(\mathrm{cm})$. A associação entre massa/volume encefálicos e os fatores relacionados (preditores) foi obtida por meio de análise univariada e multivariada. 0 p-valor foi fixado em 0,05. Resultados: Participantes era em sua maioria homens (60,4\%), com idade média de 67,1 $\pm 10,9$ anos, e caucasianos (69\%). A média de massa encefálica da amostra foi de $1219,2 \pm 140,9 \mathrm{~g}$, e a média do volume foi 1217,1 \pm $152,3 \mathrm{~mL}$. Perímetro cefálico esteve independentemente associado à redução de massa $(p<0,001)$ e volume $(p<0,001)$. Massa e volume (total e corrigido) reduziu em algumas condições. Gênero feminino $(p<0,001)$, hipertensão $(p<0,009)$,

This study was conducted at the Physiopathology in Aging Laboratory - SGHC/ LIM 22 - FMUSP.

'BSN, RN, CNS, Ph.D, Medical-Surgical Nursing Department. University of São Paulo School of Nursing. São Paulo SP, Brazil; Physiopathology on Aging Lab/ SGHC - LIM 22. University of São Paulo School of Medicine. São Paulo SP, Brazil. ${ }^{2} M D$, Ph.D, Physiopathology on Aging Lab/SGHC - LIM 22. University of São Paulo School of Medicine. São Paulo SP, Brazil. Division of Geriatrics of the Clinicas Hospital. University of São Paulo School of Medicine. São Paulo SP, Brazil. ${ }^{3 B S C}$ Ph.D, Physiopathology on Aging Lab/ SGHC - LIM 22. University of São Paulo School of Medicine. São Paulo SP, Brazil. " MD, Ph.D, Physiopathology on Aging Lab/ SGHC - LIM 22. University of São Paulo School of Medicine. São Paulo SP, Brazil; Department of Pathology. University of São Paulo School of Medicine. São Paulo

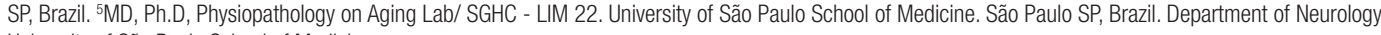
University of São Paulo School of Medicine.

Renata Eloah de Lucena Ferretti-Rebustini. Av. Dr. Enéas de Carvalho Aguiar, 419 / $3^{\circ}$ andar / Sala 354 - 05403-000 São Paulo SP - Brasil. E-mail: reloah@usp.br

Disclosure: The authors report no conflicts of interest.

Received November 26, 2014. Accepted in final form March 04, 2015. 
doença arterial coronariana $(p<0,013)$ e auxílio para deambulação $(p<0,011)$ foram fatores associados à redução da massa encefálica corrigida, enquanto a escolaridade esteve associada com seu aumento $(p<0,003)$. A idade $(p<0,001)$, 0 gênero feminino $(p<0,001)$ e a hipertensão $(p<0,011)$ estiveram associados à redução no volume encefálico corrigido. Conclusão: As alterações morfométricas encefálicas ocorrem apesar da inexistência de comprometimento cognitivo e são associadas à idade, ao gênero feminino, às alterações de mobilidade e às doenças cardiovasculares. A escolaridade parece ser um fator protetor.

Palavras-chave: envelhecimento, céfalometria, encéfalo/anatomia \& histologia, saúde do idoso

\section{INTRODUCTION}

$\mathrm{N}$ ormal and pathological brain aging has attracted great interest, largely due to the major impact of changes resulting from neurodegenerative diseases on the lives of elderly, their families and health/social support network.

Studies of morphometric brain changes have been conducted and have proven that during aging, changes in brain weight and volume occur. Controversy remains over the level at which these changes occur, due to the use of different methodological approaches. Autopsy studies and neuroimaging have shown reductions in brain weight and volume during aging. ${ }^{1-14}$ However, most studies did not adjust the measurements of brain weight and volume for head circumference, known to be a factor influencing brain weight and volume changes.

Some factors have been associated with brain aging ${ }^{3,12,14-23}$ but the role of clinical, social and demographic factors in causing morphometric brain changes remains unknown. Some studies have sought to identify factors associated with morphometric brain changes during aging, the majority of which describe the association of specific factors with cognitive impairment or neurodegenerative diseases but not with brain aging. ${ }^{24-29}$ Besides the identification of factors associated with dementia, it is necessary to understand factors related to normal brain aging. In 1988, Drayer ${ }^{14}$ suggested that the changes occurring in normal aging brains should be thoroughly studied before analyzing abnormal brains.

The objective of the present study was to identify demographic and clinical factors associated with morphometric brain changes during cognitively normal aging,

\section{METHODS}

A cross-sectional study was conducted at the São Paulo Autopsy Service (SPAS) between 2004 and 2008. In Brazil, autopsy is mandatory for all individuals whose cause of death was not identified before death. The SPAS is a general autopsy service responsible for issuing death certificates in such cases within the city of São Paulo, Brazil.

Participants. Subjects were participants of the Brazilian
Brain Bank of the Aging Brain Study group (BBBABSG). All the methodological procedures of the BBBABSG have been described elsewhere. ${ }^{30,31}$ The local Ethics Committee (CAPPesq) approved the research protocol (285/04). Briefly, participants were 50 years or older at the time of death and were referred to the SPAS for autopsy. Upon arrival of the corpses, families must come to the SPAS for funeral procedures. A team of nurses with expertise in gerontology invited a knowledgeable informant to participate in the study. A knowledgeable informant (KI) was a close family member or caregiver that has been present during the illness of the deceased and was able to recount and provide details of the deceased's health information. Subjects were included after the study procedures had been explained to the KI and they had agreed to participate by signing an Informed Consent Form (ICF).

Inclusion criteria were: subjects 50 years and older; natural cause of death (non-accidental); having a KI with close contact at least 6 months prior to death; no cognitive impairment as assessed by the Clinical Dementia Rating Scale $(C D R=0)$. Cases with cognitive decline, no reliable informant, a medical history of advanced chronic disease or prolonged agonal state were excluded. Furthermore, only complete cases were included (those having brain weight, brain volume, head circumference and clinical data available).

Procedures. Clinical Post-mortem evaluation. Clinical evaluation consisted of assessment of the deceased's clinical and functional status in the three months prior to death. Information was obtained from the KI. A semistructured clinical interview assessed demographics (gender, age and schooling), conditions related to death, past medical history (clinical and surgical), treatments, smoking habits and alcohol consumption, functional ability, and cognitive performance (assessed by the Clinical Dementia Rating Scale). ${ }^{32}$ During clinical evaluation, the interviewer continuously checked for data consistency and exclusion criteria, in order to detect any condition that might lead to the exclusion of the case. 
Morphometric measurements. At the time of autopsy, morphometric brain measurements (brain weight, volume and head circumference) were taken. Brain weight (g) was obtained by weighing the fresh brain on accurate scales upon removal from the skull. Volume $(\mathrm{mL})$ was obtained by Archimedes' Principle, ${ }^{33}$ considered a reliable procedure for measuring volume of body regions. ${ }^{34}$ The principle postulates that when an object is immersed in a given liquid, the displaced liquid represents the volume of the object below the surface..$^{35}$ Thus, the brain was immersed in water and the volume of displaced water was considered the volume of the brain.

In order to avoid the secular effect, ${ }^{1,9,36,37}$ brain weight and volume was adjusted for head circumference, resulting in adjusted brain weight $(\mathrm{g} / \mathrm{cm})$ and volume $(\mathrm{mL} / \mathrm{cm})$. Brain weight and volume decreases as head circumference decreases, justifying adjustment of these measures.

Head circumference $(\mathrm{cm})$ was obtained by placing an inelastic tape around the skull of the corpse to obtain the maximum cranium circumference, called head circumference. For this, the tape was wrapped around the skull passing through two anatomical landmarks: the glabella and opstocranium. This measure was taken before opening of the skull and removal of the brain. In all, the procedure took about 30 minutes.

Neuropathology of the cases, to test for the existence of neurodegenerative-related pathology, was not analyzed in the present study.

Statistical analysis. For the descriptive analysis of sample characteristics and morphometric measures, frequency and central tendency measures were used. Brain weight and volume were associated with some clinical and socio-demographic conditions. For this evaluation, parametric and non-parametric tests were used. The t-Test $(\mathrm{t})$ and Qui-square $\left(\mathrm{X}_{2}\right)$ test were employed to check for statistical significance of continuous and nominal data, respectively. Correlations were obtained by Pearson's Correlation Test ( $r$ ) for continuous data whereas Spearman's Correlation test (r) was used for ordinal data. Initially it was verified whether there was an association between morphometric variables (brain weight and volume) and each of the clinical and demographic variables. For the univariate analysis, Spearman's correlation and Kruskal-Wallis tests were used for quantitative and qualitative variables, respectively. A p-value of 0.05 was considered significant.

Using the stepwise forward procedure, multivariate linear regression selected all significant variables. Variables considered for inclusion in the regression models were those that obtained $\mathrm{p}<0.20$ on the Kruskal-Wallis test. Suppositions for the adjustment of the models were performed by residual analysis. Interpretation of estimated coefficients was carried out by considering the reference categories as follows: female for gender; no hypertension; no coronary artery disease and no walking assistance.

\section{RESULTS}

Participants ( $\mathrm{n}=414)$ were predominantly male $(\mathrm{n}=250$; $60.4 \%)$, Caucasian (69.0\%) and had a mean age of $67.1 \pm$ 10.9 years. Mean age among males was $68.5 \pm 11.9$ years and among females was $66.2 \pm 10.2$ years. Mean brain weight was $1219.2 \pm 140.9 \mathrm{~g}$, and mean brain volume was $1217.1 \pm 152.3 \mathrm{~mL}$.

Adjusted brain weight and volume inversely correlated with age $(\mathrm{r}-0.291, \mathrm{p}<0.001 ; \mathrm{r}-0.259, \mathrm{p}<0.001)$, meaning that both brain weight and volume reduced during the normal aging process. Adjusted brain weight and volume increased with greater years of study ( $r$ $0.239, \mathrm{p}<0.001 ; \mathrm{r} 0.166, \mathrm{p}<0.001$ ).

Average brain weight of individuals with previous medically diagnosed conditions was lower than for donors who had no medical condition diagnosed in life $(p<0.05)$, irrespective of disease (Table 1$)$. However, significant differences in average brain volume for previous medical condition in life were not found $(\mathrm{p}<0.09)$.

The univariate analysis of data evidenced that having reported some previous diagnosis in life was statistically associated with lower brain weight $(\mathrm{p}<0.02)$ but not with brain volume $(\mathrm{p}<0.15)$. Hypertension, smoking habits and the ability to walk without any kind of assistance (walking ability) were the only variables associated with lower brain weight and volume (total and adjusted) (Table 2).

Head circumference, female gender, hypertension, coronary artery disease and walking assistance were associated with brain changes during aging. Schooling, understood as the number of formal years of education at school, was a protective factor against low brain weight. Regression models are shown in Table 3.

Men had $1.03 \mathrm{~g} / \mathrm{cm}(\mathrm{p}<0.001)$ higher adjusted brain weight than women. There was a $0.07 \mathrm{~g} / \mathrm{cm}(\mathrm{p}<0.003)$ increase in adjusted brain weight for each year of schooling. A $0.04 \mathrm{~g} / \mathrm{cm}$ reduction in adjusted brain weight was observed for each year of age $(\mathrm{p}<0.001) ; 0.46 \mathrm{~g} / \mathrm{cm}$ $(p<0.009)$ in the presence of hypertension; $0.53 \mathrm{~g} / \mathrm{cm}$ $(\mathrm{p}<0.013)$ in coronary artery disease; and $0.60 \mathrm{~g} / \mathrm{cm}$ if the person required assistance walking. Men also had greater adjusted brain volume than women $(0.96 \mathrm{~mL} /$ $\mathrm{cm} ; \mathrm{p}<0.001$ ). Adjusted brain volume decreased by 0.05 
Table 1. Descriptive statistics for brain weight and volume (total and adjusted for head circumference), according to selected comorbidities during life.

\begin{tabular}{|c|c|c|c|c|c|c|c|c|c|}
\hline \multirow[b]{2}{*}{ Comorbidity } & \multirow[b]{2}{*}{ N (\%) } & \multicolumn{2}{|c|}{ Mean weight } & \multicolumn{2}{|c|}{ Standard deviation } & \multicolumn{2}{|c|}{ Mean volume } & \multicolumn{2}{|c|}{ Standard deviation } \\
\hline & & $\begin{array}{l}\text { Total } \\
\text { (g) }\end{array}$ & $\begin{array}{l}\text { Adjusted* } \\
\text { (g/cm) }\end{array}$ & $\begin{array}{c}\text { Total } \\
\text { (g) }\end{array}$ & $\begin{array}{c}\text { Adjusted* }^{*} \\
\text { (g/cm) }\end{array}$ & $\begin{array}{l}\text { Total } \\
(\mathrm{mL})\end{array}$ & $\begin{array}{l}\text { Adjusted* } \\
\text { (mL/cm) }\end{array}$ & $\begin{array}{l}\text { Total } \\
(\mathrm{mL})\end{array}$ & $\begin{array}{l}\text { Adjusted }^{*} \\
\text { (mL/cm) }\end{array}$ \\
\hline None $^{\star \star}$ & $65(15.7)$ & 1258.3 & 22.5 & 140.1 & 2.2 & 1256.9 & 22.5 & 179.4 & 2.9 \\
\hline Stroke & $47(11.4)$ & 1191.8 & 21.5 & 150.9 & 3.0 & 1208.0 & 21.8 & 143.1 & 3.0 \\
\hline Parkinson's & $3(0.7)$ & 1108.3 & 19.5 & 125.7 & 1.2 & 1066.7 & 18.8 & 125.8 & 1.4 \\
\hline Depression & $15(3.6)$ & 1186.7 & 21.2 & 98.6 & 1.5 & 1216.7 & 21.7 & 95.7 & 1.5 \\
\hline COPD & $34(8.3)$ & 1194.9 & 21.3 & 139.6 & 2.3 & 1200.6 & 20.6 & 145.9 & 2.3 \\
\hline Hypertension & $269(65.1)$ & 1206.9 & 21.4 & 149.3 & 2.5 & 1199.0 & 21.3 & 147.0 & 2.4 \\
\hline CAD & $71(17.2)$ & 1211.5 & 21.3 & 144.8 & 2.1 & 1213.2 & 21.2 & 162.0 & 2.4 \\
\hline Heart failure & 85 (20.6) & 1214.3 & 21.4 & 133.5 & 1.8 & 1216.5 & 21.4 & 153.4 & 2.2 \\
\hline Arrhythmia & $43(10.4)$ & 1233.9 & 21.7 & 139.4 & 2.5 & 1246.6 & 22.0 & 129.8 & 2.1 \\
\hline PVD & $8(1.9)$ & 1212.9 & 21.2 & 135.8 & 1.5 & 1228.7 & 21.4 & 222.7 & 2.9 \\
\hline Diabetes & $118(28.6)$ & 1207.9 & 21.4 & 130.2 & 1.9 & 1218.0 & 21.6 & 141.9 & 2.6 \\
\hline Thyroid & $5(1.2)$ & 1201.0 & 21.5 & 92.9 & 1.9 & 1220.0 & 21.8 & 67.1 & 0.8 \\
\hline Dyslipidemia & $45(10.9)$ & 1199.9 & 21.2 & 118.6 & 1.8 & 1212.4 & 21.4 & 142.7 & 2.3 \\
\hline Cancer & $32(7.7)$ & 1209.5 & 21.8 & 88.1 & 1.5 & 1230.9 & 22.2 & 117.4 & 2.3 \\
\hline
\end{tabular}

*Adjusted for head circumference. ${ }^{\star *}$ No history of diagnosed disease in life. COPD: chronic pulmonary disease; CAD: coronary artery disease; PVD: peripheral vascular disease.

Table 2. P-values obtained by Kruskal-Wallis test for comparison of distribution of Brain Weight and Volume for clinical variables.

\begin{tabular}{|c|c|c|c|c|}
\hline & \multicolumn{2}{|c|}{ Brain weight } & \multicolumn{2}{|c|}{ Brain volume } \\
\hline & Total & Adjusted & Total & Adjusted \\
\hline Positive personal history of disease & 0.023 & 0.003 & 0.156 & 0.123 \\
\hline Stroke & 0.057 & 0.060 & 0.720 & 0.937 \\
\hline Parkinson's disease & 0.141 & 0.044 & 0.069 & 0.032 \\
\hline Depression & 0.328 & 0.296 & 0.893 & 0.754 \\
\hline Chronic obstructive pulmonary disease & 0.863 & 0.951 & 0.774 & 0.873 \\
\hline Hypertension & 0.001 & 0.000 & 0.006 & 0.001 \\
\hline Coronary artery disease & 0.392 & 0.012 & 0.739 & 0.180 \\
\hline Congestive heart failure & 0.756 & 0.157 & 0.888 & 0.479 \\
\hline Arrhythmia & 0.398 & 0.535 & 0.132 & 0.143 \\
\hline Vascular disease & 0.939 & 0.478 & 0.455 & 0.655 \\
\hline Diabetes mellitus & 0.452 & 0.207 & 0.753 & 0.655 \\
\hline Thyroid disease & 0.826 & 0.909 & 0.720 & 0.549 \\
\hline Dyslipidemia & 0.336 & 0.090 & 0.915 & 0.626 \\
\hline Cancer & 0.878 & 0.377 & 0.559 & 0.153 \\
\hline Visual impairment & 0.166 & 0.436 & 0.176 & 0.421 \\
\hline Hearing loss & 0.735 & 0.906 & 0.628 & 0.328 \\
\hline Smoking habit & 0.000 & 0.000 & 0.002 & 0.013 \\
\hline Alcohol consumption & 0.001 & 0.030 & 0.035 & 0.420 \\
\hline Walking assistance & 0.000 & 0.000 & 0.001 & 0.005 \\
\hline Physical activity practice & 0.489 & 0.533 & 0.983 & 0.866 \\
\hline
\end{tabular}


Table 3. Regression model for total and adjusted brain weight and volume.

\begin{tabular}{|c|c|c|c|c|c|c|}
\hline \multirow[b]{2}{*}{ Variable } & \multicolumn{3}{|c|}{ Brain weight } & \multicolumn{3}{|c|}{ Adjusted brain weight } \\
\hline & Coefficient $\beta$ & Standard error & P-value & Coefficient $\beta$ & Standard error & P-value \\
\hline Constant & 117.7 & 114.1 & 0.303 & 23.56 & 0.54 & 0.000 \\
\hline Head circumference & 21.4 & 1.971 & 0.000 & - & - & - \\
\hline Gender & 57.5 & 10.42 & 0.000 & 1.03 & 0.17 & 0.000 \\
\hline Age & -1.96 & 0.426 & 0.000 & -0.04 & 0.01 & 0.000 \\
\hline Schooling & 3.4 & 1.287 & 0.009 & 0.07 & 0.02 & 0.003 \\
\hline Coronary artery disease & - & - & - & -0.53 & 0.21 & 0.013 \\
\hline Hypertension & -31.0 & 9.902 & 0.002 & 0.46 & 0.18 & 0.009 \\
\hline Walking assistance & -35.3 & 13.29 & 0.008 & -0.60 & 0.23 & 0.011 \\
\hline \multirow[t]{2}{*}{ Bedridden state } & -43.6 & 24.59 & 0.077 & -0.81 & 0.43 & 0.062 \\
\hline & \multicolumn{3}{|c|}{ Brain volume } & \multicolumn{3}{|c|}{ Adjusted brain volume } \\
\hline Variable & Coefficient $\beta$ & Standard error & P-value & Coefficient $\beta$ & Standard error & P-value \\
\hline Constant & 116.4 & 161.5 & 0.471 & 24.82 & 0.74 & 0.000 \\
\hline Head circumference & 22.8 & 2.8 & 0.000 & - & - & - \\
\hline Gender & 51.9 & 14.6 & 0.000 & 0.96 & 0.23 & 0.000 \\
\hline Age & -2.8 & 0.6 & 0.000 & -0.05 & 0.01 & 0.000 \\
\hline Hypertension & -35.3 & 13.8 & 0.011 & -0.62 & 0.24 & 0.010 \\
\hline
\end{tabular}

$\mathrm{mL} / \mathrm{cm}$ for each year of age and in the presence of hypertension $(0.62 \mathrm{~mL} / \mathrm{cm} ; \mathrm{p}<0.010)$.

\section{DISCUSSION}

The present study demonstrated that age, female gender, coronary artery disease, hypertension, and the need of assistance for walking were associated with morphometric brain changes during cognitively normal aging. Some demographic and clinical factors were associated with low or high brain weight and volume. We also demonstrated that schooling was associated with higher brain weight. According to Benedetti et al. (2006), changes in brain weight and volume are the result of a complex phenomenon caused by the association of many factors. ${ }^{38}$ It seems that lifestyle might play an important role in cognitive impairment. Also, it has been demonstrated that global atrophy observed in healthy subjects is lower than that observed in sick individuals. ${ }^{18}$

Age and gender were inversely correlated with morphometric brain measurements. Females had lower brain weight and volume when compared to men. In addition, brain weight and volume decreased with age. Previous studies have demonstrated the same association. 1 , 4-6,8,12,13,17,38 The weakness of the correlations may lead to the conclusion that other factors, besides age and gender, also contribute to the phenomenon.

Formal education has been shown to be a protective factor. ${ }^{39,40}$ In the present study, there was an association between schooling and brain weight and volume. More years of education was associated with greater brain weight and volume.

Some risk factors have been associated with accelerated brain and volume reductions and worse cognitive performance during aging, such as hypertension, diabetes, dyslipidemia, alcohol consumption, smoking habits, obesity, physical inactivity and elevated plasma homocysteine level. ${ }^{15,16,18,20-22,27,42,43}$ In the present series, stroke, Parkinson's disease, hypertension, coronary artery disease, smoking habits, alcohol consumption and walking assistance were positively associated with lower brain weight or volume, but only coronary artery disease and hypertension remained in the final regression model.

The results of the multivariate analysis lead to a better understanding of the role of each factor associated with brain weight and volume changes. Age, femalegender and hypertension were correlated with lower brain weight and volume in the total and adjusted regression models.

Head circumference also influenced brain weight and volume, increasing these parameters by $2.4 \mathrm{~g}$ and $2.8 \mathrm{~mL}$, respectively, for each additional centimeter of circumference. Despite the observation of an increase in brain weight and volume with increased years of schooling, the correlation was verified only for brain weight but not for volume. Some subjects may exhibit superior functioning even in the presence of neuropathology. 
This is attributed to the so-called reserve. ${ }^{39}$ Cognitive reserve probably implies brain reserve, ${ }^{40,41}$ related to brain mass. Further studies correlating the interactions between schooling and volume might allow more conclusive interpretations.

Heart failure, described elsewhere as responsible for brain changes, ${ }^{16-19,24}$ was not associated with brain weight or volume in the present study. Likewise, depression did not correlate with morphometric brain changes, in contrast to previous studies which have demonstrated this interaction. ${ }^{44}$ This disparity is probably because the detection of Depression in the present sample, as a medical condition diagnosed in life, was based on a collateral source while the overall number of subjects with established depression diagnosis in life was small. Diabetes has been described as an important factor related to brain weight and volume ${ }^{18}$ but this association was not found in the present study. This absence of association also occurred for physical activity, which may be explained by the sample profile of sedentary elderly subjects.

Cardiovascular risk factors have been implicated for increased mortality rates and morbidity among elderly, ${ }^{45,46}$ especially when in association with psychiatric morbidity. Many factors can contribute to brain weight in subjects with cardiovascular disease. Cardiovascular risk factors are associated with strokes and white matter lesions, which might contribute to cognitive decline, depending on their location, type and number. ${ }^{47}$ Atrial fibrillation, heart failure and hypertension may lead to reduced blood flow to the brain with decreased tissue perfusion or bleeding. This may contribute to a decrease in supply of oxygen and other nutrients to the brain, resulting in cognitive impairment and brain atrophy. ${ }^{16,47}$ Nevertheless, not all the cardiovascular risk factors investigated in the present study were selected for inclusion in the regression model. Hypertension alone, was responsible for a $34 \mathrm{~g}$ reduction in brain weight.

The strength of this study is the clinicopathological assessment of the subjects in a post-mortem setting, which allowed direct brain morphometric measurements in an adequate number of cases. The frequency of autopsies is decreasing worldwide. In Brazil, autopsy procedures are mandatory for all subjects who die without a defined medical condition. Consequently, the number of cases submitted to autopsy every year is huge.

Another strength of the present study is the sample comprising cognitively normal subjects. This characteristic is important because all the findings of the study relate to a sample comprising subjects without cognitive impairment. Morphometric brain changes were present during aging but were not sufficient to cause cognitive impairment or dementia. The primary hypothesis is that, as occurs in other organisms, there is a brain reserve (cerebral reserve) capable of maintaining cognitive brain function under normal conditions. Brain aging involving isolated morphometric changes is not associated with cognitive impairment.

One of the study limitations is the fact that the presence of neuropathological lesions, such as neurofibrillary tangles, senile plaques, infarcts, or synucleinopathies, which can explain brain atrophy, were not analyzed. Neuropathological lesions may play an important role in reducing brain weight and volume. The contribution of these lesions to morphometric changes, associated with other changes, could not be determined due to the lack of neuropathology.

Another limitation was that cross-sectional studies are not sufficient to establish causality, but can reveal associations. Longitudinal studies, with brain donation in life, could contribute to a better understanding of the process. Additionally, the postmortem assessment of cognitive function and the fact that informants reported all medical conditions can also be considered a limitation.

Finally, the results of this study are important to public health. Since it is known that some diseases and life-styles are associated with morphometric brain changes during aging and that these changes can reduce brain reserve and contribute to cognitive decline, efforts have to be made toward preventing these conditions and reinforcing public health measures, related to health promotion.

Author contributions. Renata Eloah de Lucena FerrettiRebustini contributed to the conception and design of the study, data acquisition, data analysis with interpretation of results and writing of the manuscript. Wilson Jacob-Filho contributed to the conception and design of the study, interpretation of results and writing of the manuscript. Claudia Kimie Suemoto, José Marcelo Farfel, Renata Elaine Paraiso Leite, Lea Tenenholz Grinberg contributed to data acquisition, interpretation of results and writing of the manuscript. Carlos Augusto Pasqualucci and Ricardo Nitrini contributed to interpretation of results and writing of the manuscript. All authors contributed with critical revision of the manuscript for important content.

Acknowledgments. We acknowledge the contributions of all the families who voluntarily accepted to participate by donating brains for use in scientific research. We also acknowledge the SPAS staff and the Brazilian Brain 
Bank of the Ageing Brain Study Group for participating in the selection, inclusion and processing of the cases.
Support. Funding was provided by the Physiopathology in Aging Laboratory - SGHC/ LIM 22 - FMUSP.

\section{REFERENCES}

1. Ferretti REL, Jaco-Filho W, Grinberg LT, et al. Morphometric Brain changes during ageing: results from a Brazilian necropsy sample. Dement Neuropsychol 2010;4(4):332-337.

2. Esiri MM. Ageing and the brain. J Pathol 2007:211:181-187

3. Carne RP, Vogrin S, Litewka L, et al. Cerebral Cortex: an MRI-based study of volume and variance with age and sex. J Clinical Neuroscience 2006;13:60-72.

4. Witelson SF, Beresh H, Kigar DL. Intelligence and brain size in 100 postmortem brains: sex, lateralization and age factors. Brain 2006;129: 386-398.

5. Lemaître H, Crivello F, Grassiot B, et al. Age-related and sex-related effects on the neuroanatomy of health elderly. Neuroimage 2005;26: 900-911.

6. Jerningan TL, Archibald SL, Fennema-Notestine C, et al. Effects of age on tissues an regions of the cerebrum and cerebellum. Neurobiol Aging 2001;22:581-594.

7. Biglar ED, Neely ES, Miller MJ, et al. Cerebral volume loss, cognitive deficit and neuropsychological performance: comparative measures of brain atrophy: I-Dementia. J Int Neuropsychol Soc 2004;10:442-452.

8. Anderton BH. Ageing of the brain. Mec Ageing Dev 2002;123:811-817.

9. Good CD, Johnsrude IS, Ashburner J, et al. A voxel-based morphometric study of aging in 465 normal adult human brains. Neuroimage 2001;14:21-36

10. Courchesne E, Chisum HJ, Townsend J, et al. Normal brain development and aging: quantitative analysis at in vivo $\mathrm{MRI}$ in health volunteers. Radiology 2000;216(3):672-682.

11. Mrak RE, Griffin ST, Graham DI. Aging-associated changes in human brain. J Neuropathol Exp Neurol 1997;56(12):1269-1275.

12. Sánchez R, Morales M, Carozo J. peso del encéfalo normal del venezuelano adulto según sexo y edad. Invest Clin 1997;38(2):83-93.

13. Coffey CE, Wiiiiilkinson WE, Parashos IA, et al. Quantitative cerebral anatomy of the aging human brain: a cross-sectional study using magnetic resonance imaging. Neurology 1992;42:527-536.

14. Drayer BP. Imageing of the ageing brain - part I: normal findings. Radiology 1998;166:785-796.

15. Taki Y, Kinomura S, Sato K, et al. Both gray matter volume and regional gray matter volume negatively correlate with lifetime alcohol intake in non-alcohol dependent Japanese men: a volumetric analysis and a voxelbased morphometry. Alchohol Clin Exp Res 2006;30(6):1045-1050.

16. Alves TCTF, Wajngarten M, Bussato-Filho G. Fatores de risco cardiovascular, declínio cognitivo e alterações cerebrais detectadas através de técnicas de neuroimagemm. Rev Psiq Clin 2005;32(3):160-169.

17. DeCarli C, Massaro J, Harvey D, et al. Measures of brain morphology and infarction in the Framingham Heart Study: establishing what is normal. Neurobiol Aging 2005;26:491-510.

18. Enzinger C, Fazekas F, Matthews PM, et al. Risk factors for progression of brain atrophy in aging: six-year follow up of normal subjects. Neurology 2005;64:1704-1711.

19. Ward MA, Carlsson CM, Trivedi MA, et al. The effect of body mass index on global brain volume in middle-aged adults: a cross-sectional study. BMC Neurol 2005;5923):1-7.

20. Jagust $W$, Havey $D$, Mungas $D$, et al. Central obesity and the aging brain. Arch Neurol 2005;62(10):1545-1548

21. Colcombe SJ, Erickson $\mathrm{Kl}$, Raz N, et al. Aerobic fitness reduces brain tissues loss in aging humans. J Gerontology 2003;58A(2):176-180.

22. Colcombe SJ, Kramer A. Fitness effect on the function of older adults: a meta-analytic study. Psychol Sci 2003;14(2):125-130.

23. Pfefferbaum A, Rosenbloom M, Deshmukh A, et al. Sex differences in the effects of alcohol on bran structure. Am J Pshychiatr 2001;158:188-197.

24. Qiu C, Winblad B, Marengoni A, et al. heart failure and risk of dementia and Alzheimer's Disease: a population based cohort study. Arch Intern Med 2006;166:1003-1008
25. Scarmeas N, Stern Y, Mayeux R, et al. Mediterranean diet, Alzheimer's disease and vascular mediation. Arch Neurol 2006;63:E1-E9.

26. Sturman MT, Morris MC, leon CFM, et al. Physical Activity, Cognitive Activity, and Cognitive Decline in a Biracial Community Population. Arch Neurol 2005;62:1750-1754

27. Luchsinger JA, Reitz C, Honig LS, et al. Aggregation of vascular risk factors and risk of incident Alzheimer's disease. Neurology 2005;65: 545-551.

28. Daminani IT, Gagliardi RJ, Scaff M. Influência do etanol das bebidas alcoólicas na ateroesclerose em artérias carótidas extracranianas. Arq Neuropsiquiatr 2004;62(4):1022-1026.

29. Wang LY, Larson EB, Sonnen JA, et al. Blood pressure and brain injury in older adults: finding from a community-based autopsy study. J Am Geriatric Soc 2009;57(11):1975-1981.

30. Grinberg LT, Ferretti REL, Farfel JM, et al. Brain Bank of the Brazilian ageing brain study group-a milestone reached and more than 1.600 collected brains. Cell Tissue Bank 2007;8(2):151-162.

31. Ferretti REL, Grinberg LT, Leite REP, et al. banco de Encéfalos Humanos: uma ferramenta importante para o estudo do envelhecimento cerebral. Rev O mundo da Saúde 2009;33(1):89-98.

32. Morris JC. The clinical dementia rating (CDR): current version and scoring rules. Neurology 1993;43(11):2412-2414.

33. Heath TL. The method of Archimedes recently discovered by Heiberg: a supplement to the works of Archimedes, 1897. London: Cambridge University Press, 1912

34. Tie K, Wang H, Wang X, Chen L. Measurement of Bone Mineral Density in the Tunnel Regions for Anterior Cruciate Ligament Reconstruction by Dual-Energy X-Ray Absorptiometry, Computed Tomography Scan, and the Immersion Technique Based on Archimedes' Principle. Arthroscopy 2012;28(10):1464-71.

35. Simanek DE. Archimedes Principle. Available on: http://www.lhup. edu/ dsimanek/scenario/labman1/archim.htm. Acessed on 24/04/15.

36. Miller $\mathrm{AKH}$, Corsellis JAN. Evidence for a secular increase in human brain weight during the past century. Ann Hum Biol 1977;4:253-257.

37. Mrak RE, Griffin ST, Graham DI. Aging associated changes in human brain. J Neuropatol Exp Neurol 1997;56(12):1269-1275.

38. Benedetti B, Charil A, Rovaris M, et al. Influence of ageing on brain gray and white matter changes assessed by conventional MT and DT MRI. Neurology 2006;66:535-539.

39. Stern Y. Cognitive reserve: implications for assessment and intervention. Folia Phoniatr Logop 2013;65:49-54

40. Stern Y. The concept of cognitive reserve: a catalyst for research. J Clin Exp Neuropsychology 2003;25(5):589-593.

41. Richards M, Deary IJ. A life course approach to cognitive reserve: a model for aging and development? Ann Neurol 2005;58:617-622.

42. Borestein AR, Wu Y, Mortimer JA, et al. Developemental and vascular risk factors for Alzheimer's Disease. Neurobiol Aging 2005;16:325-334.

43. Lautenschlager NT. Is it possible to prevent dementia? Rev Bras Psiquiatr 2002;24(Supl1):22-27

44. Bottino CMC. Morfometria por ressonância magnética. Rev Psiquiatr Clin 2000;27:3. Available online in http://www.hcnet.usp.br/ipq/revista/ vol27/n3/art131.htm. Access in 20/08/2013.

45. Mathias TAF, Jorge MHPM, Laurenti R. Doenças Cardiovasculares na População Idosa. Análise do Comportamento da Mortalidade em Município da Região Sul do Brasil no Período de 1979 a 1998. Arq Bras Cardiol 2004;82(6):533-541.

46. Lima-Costa MF, Pixoto SV, Giatti L. Tendências da mortalidade entre idosos brasileiros (1980-2000). Epidemiol Serv Saúde 2004;13(4): 217-228.

47. Snowdown DA. Healthy aging and dementia: findings from the nun study. Ann Intern Med 2003;139:450-454 